\title{
Resiliensi ibu dengan anak autisme
}

\author{
Claudia Putu Desiana Chyntia Dewi dan Putu Nugrahaeni Widiasavitri \\ Program Studi Psikologi, Fakultas Kedokteran, Universitas Udayana \\ putu_nugrahaeni@unud.ac.id
}

\begin{abstract}
Abstrak
Kehadiran anak dengan gangguan autisme di tengah-tengah keluarga menjadi pengalaman tersendiri bagi ibu dalam mendampingi dan mengasuh anak dengan autisme, yang dapat menimbulkan perubahan besar dan krisis bagi ibu. Ketidakmampuan ibu dalam mengatasi krisis yang dialami dapat mengganggu fungsi dan peran ibu terkait pengasuhan. Resiliensi menjadi salah satu faktor yang membantu ibu dalam menjalankan peran pengasuhan secara optimal. Penelitian ini bertujuan untuk melihat gambaran resiliensi ibu dengan anak autisme. Metode penelitian yang digunakan adalah penelitian kualitatif dengan pendekatan fenomenologi. Teknik pengambilan sampel adalah purposive sampling. Responden yang terlibat di dalam penelitian ini adalah ibu yang memiliki anak dengan gangguan autisme. Data dikumpulkan dengan melakukan wawancara, observasi, dan laporan diri responden. Data yang terkumpul dianalisis dengan theoretical coding dari Strauss dan Corbin. Hasil penelitian menunjukkan bahwa ibu melakukan mekanisme penyesuaian diri dan mekanisme koping dalam usaha mencapai resiliensi. Mekanisme penyesuaian diri yang dikembangkan oleh ibu dengan anak autisme dibagi menjadi dua yaitu mekanisme penyesuaian terhadap karakteristik anak dan mekanisme penyesuaian terhadap respon lingkungan sekitar. Sedangkan mekanisme koping yang dikembangkan berupa kontrol diri, berpasrah, melakukan pengalihan, mencari informasi, mencari bantuan, dan pemecahan masalah bersama.
\end{abstract}

Kata Kunci: Ibu dengan anak autisme, Resiliensi

\begin{abstract}
The presence of child who has autism disorder in a family become its own experience for the mother who accompany and take care her child, which can cause major changes and crisis to her. The disability of a mother handling the crisis can interrupts the function and her role as mother in term of caring. Resilience is one of the factors that helps mother in carrying out optimal parenting role. This research has a purpose to look at the the resilience of a mother with autism children. The method that use in this research is qualitative method with phenomenology approach. The technic to collect sample is purposive sampling. Respondents whose involve in this research is a mother who had a child with autism disorder. The data is collected by doing interview, observation, and respondent self-report. The data that gathered is analyzed with theoretical coding by Strauss and Corbin. Result of this research shows that a mother is doing adjustment mechanism and coping mechanism in order to achieve resilience. Adjustment mechanism which developed by a mother who had child with autism disorder is divided into two mechanism which are adjustment mechanism to child character and adjustment mechanism to the respond of the child to their surrounding environment. Meanwhile coping mechanism that developed by self-control, resignation to God, make a diversion, seeking information, seeking help, and solving problems together.
\end{abstract}

Keywords: a Mother of children with autism, Resilience 


\section{LATAR BELAKANG}

Menikah dan menjadi orangtua merupakan salah satu peran yang penting dalam hidup orang dewasa yang menuntut tanggung jawab dalam menghadapi setiap tantangan tugas pengasuhan. Terutama bagi orangtua yang memiliki anak berkebutuhan khusus. Merawat, mendidik, dan mengasuh anak berkebutuhan khusus memiliki tantangan tersendiri bagi mereka dan tentunya hal ini tidak dapat disamaratakan dengan orangtua lainnya (Hertianna, 2013). Anak berkebutuhan khusus adalah anak yang memiliki keunikan tersendiri yang membedakan mereka dari anak-anak normal pada umumnya (Fitri, 2017). Dewasa ini, seringkali dijumpai anak berkebutuhan khusus yang mengalami masalah-masalah di dalam pertumbuhan dan perkembangan salah satunya adalah gangguan autisme (Rahayu, Karini, \& Karyanta, 2014). Berdasarkan penelitian diperkirakan prevalensi autisme meningkat 10-12/10.000 individu (Faradz, 2003).

Autisme menurut Diagnostic and Statistical Manual of Mental Disorder (APA, 2013) merupakan suatu gangguan perkembangan yang melibatkan berbagai perilaku bermasalah termasuk diantaranya masalah berkomunikasi, masalah persepsi, masalah motorik, dan perkembangan sosial, dimana gejala tersebut dapat terlihat sejak anak berusia dini yang muncul sebelum anak berusia tiga tahun dengan persentase empat sampai lima kali lebih sering terjadi pada anak laki-laki.

Kehadiran seorang anak dengan gangguan autisme di tengahtengah keluarga tentunya memunculkan berbagai reaksi. Orangtua dengan anak berkebutuhan khusus mengalami tiga tahapan reaksi dalam menghadapi keadaan anaknya (Hartuti \& Mangunsong, 2009). Pertama, perasaan shock, mengalami goncangan batin, terkejut dan tidak memercayai kenyataan yang dialami anaknya. Kedua, orangtua akan merasa kecewa, sedih dan mungkin merasa marah ketika mereka mengetahui realitas yang harus dihadapi. Pada tahap ketiga, terjadi tahap penerimaan dan orangtua mulai bisa menyesuaikan diri dengan keadaan anaknya.

Bagaimanapun anak dengan gangguan autisme tetaplah seorang anak yang membutuhkan kasih sayang, perhatian dan cinta dari orangtua, saudara, dan keluarganya (Safaria, 2005) serta bimbingan dari lingkungan dan orangtuanya untuk tumbuh dan berkembang agar dapat hidup dengan mandiri (Pamungkas, 2015). Disabilitas yang dimiliki oleh anak dengan gangguan autisme menuntut tanggung jawab orangtua dalam memberikan pengasuhan dan penanganan yang tepat agar dapat mengoptimalkan kemampuan yang dimiliki anak.

Ibu merupakan sosok yang dipandang memiliki hubungan terdekat dengan anak karena keterlibatannya secara penuh dalam mengasuh dan mengawal tumbuh kembang anak (Cohen \& Volkmar, 1997). Di dalam sebuah keluarga, ibu adalah sosok yang memiliki peran yang sangat besar dan penting dalam proses tumbuh kembang anak.

Peran perempuan sebagai seorang ibu merupakan sumber stres itu sendiri dan stres itu akan semakin besar jika ibu memiliki anak penyandang cacat (Bania dalam Ayu, 2012). Ibu yang memiliki anak dengan gangguan autisme menghabiskan waktu yang lebih secara signifikan dalam pengasuhan anaknya, yang tentu menimbulkan tekanan dan stres bagi ibu sendiri. Penelitian Phelps, McCammon, Wuensch, \& Golden (2009) membuktikan bahwa dari beberapa orangtua yang memiliki anak cacat atau gangguan diantaranya down syndrome, Tourette syndrome, autisme, dan ADHD, menemukan bahwa yang memiliki tingkat stres pengasuhan tertinggi adalah orangtua dari anak dengan sindrom autisme. Stres yang lebih besar berhubungan dengan perawatan anak penyandang autis yang dirasakan sangat berat oleh ibu, dimana perilaku yang muncul pada anak penyandang autis menyebabkan ibu harus ekstra 24 jam mengawasi anaknya, sehingga berpengaruh pada pekerjaan dan waktu istirahat ibu (Burrows, 2010). Ibu juga harus mengerahkan usaha yang lebih dalam mengasuh dan memberikan perhatian kepada anak mereka yang mengalami gangguan autisme (Pottie, Cohen, \& Ingram, 2008). Stigma atau pandangan negatif yang muncul terhadap anak dengan gangguan autisme juga menjadi beban tersendiri bagi ibu yang memiliki anak dengan gangguan autisme. Tidak hanya masyarakat umum, institusi-institusi pendidikan formal juga kerap kali menolak anak-anak dengan gangguan autisme (Veague, 2010).

Berbagai tekanan dan gejolak emosi muncul dalam diri seorang ibu yang dapat mengganggu kondisi baik secara fisik maupun psikis. Respon ibu terhadap tekanan dan stres yang dihadapi tidak hanya berdampak bagi dirinya sendiri tetapi juga akan berdampak pada keadaan anak dengan gangguan autisme dan ketidakmampuan ibu dalam beradaptasi dengan tekanan tersebut akan berakibat buruk dalam pengasuhan. Ibu yang tidak bisa menerima kenyataan atas kondisi anaknya hanya akan terpuruk dan bahkan tidak mau melakukan apapun untuk mendukung perkembangan anaknya. Akibatnya, ibu hanya berdiam diri dan kondisi gangguan yang dialami oleh anak semakin parah (Pamungkas, 2015).

Hadirnya anak autisme di tengah-tengah keluarga menjadi pengalaman tersendiri bagi ibu dalam mengasuh anak autisme yang menimbulkan perubahan yang besar dalam diri ibu. Hasil penelitian Widodo (2008) diketahui bahwa semangat yang tinggi dari seorang ibu untuk memperjuangkan kesembuhan anak autisnya dapat mengubah kehidupan ibu itu sendiri. Pada dasarnya, setiap individu dapat pulih kembali setelah mengalami keadaan-keadaan yang penuh tekanan dalam hidupnya tanpa mengganggu keberfungsian dirinya sebagai seorang individu seperti semula yang disebut dengan resiliensi (Reivich \& Shatte, 2002).

Reich, Zautra, \& Hall (2010) mendefinisikan resiliensi sebagai hasil dari adaptasi yang sukses terhadap kesulitan. Indikasi seseorang yang resilien apabila terdapat keseimbangan antara risk factors (faktor-faktor berisiko) dan protective factors (faktor-faktor pelindung) sebagai hasil adaptasi yang diperoleh secara individual maupun dari lingkungan, yang memampukan seseorang untuk mengembangkan diri menuju ke arah yang lebih baik (Suyasa \& Wijaya, 2006). Ibu yang telah beresiliensi memiliki kapasitas untuk dapat berespon secara sehat dan produktif serta dapat mengatasi dan mengelola stres yang 
dihadapi dalam kehidupan sehari-hari terlebih dalam tugas pengasuhan.

Menjadi individu yang beresiliensi tidak hanya berdampak positif bagi diri ibu itu sendiri, melainkan dapat menunjang perkembangan hidup anak secara optimal dan dapat membantu anak yang mengalami gangguan autisme untuk dapat hidup secara mandiri dikemudian hari. Ketidakmampuan ibu untuk mencapai resiliensi diri dapat mengganggu fungsi dan peran ibu terutama dalam tugas pengasuhan. Berdasarkan hal tersebut, penelitian ini bertujuan untuk mengetahui gambaran resiliensi Ibu yang memiliki anak dengan gangguan autisme.

\section{METODE PENELITIAN}

\section{Tipe Penelitian}

Penelitian ini menggunakan metode penelitian kualitatif dengan pendekatan fenomenologi. Pemilihan pendekatan fenomenologi di dalam penelitian ini bertujuan untuk mengetahui pengalaman - pengalaman subjektif dari responden, mengungkapkan, memelajari, dan memahami resiliensi ibu yang memiliki anak dengan gangguan autisme berdasarkan sudut pandang, paradigma, dan keyakinan dari responden yang bersangkutan.

Penelitian ini melibatkan tiga orang ibu yang memiliki anak dengan gangguan autisme. Secara terperinci karakteristik responden yang dilibatkan dalam penelitian ini adalah sebagai berikut: Ibu yang memiliki anak dengan gangguan autism, berdomisili di Bali, dan bersedia menjadi responden sejak awal hingga akhir penelitian.

Responden dalam penelitian ini merupakan tiga orang ibu dengan anak autisme. Responden pertama yaitu responden AS yang memiliki seorang anak perempuan yang mengalami gangguan autisme dan saat ini telah berusia 10 tahun. Anak responden AS didiagnosa mengalami gangguan autisme ketika anak berusia sekitar dua tahun.

Responden kedua yaitu responden STW memiliki empat orang anak, dimana anak keempat dari responden STW yang berjenis kelamin perempuan mengalami gangguan autisme. Saat ini anak responden STW berusia 13 tahun. Anak responden STW didiagnosa mengalami gangguan autisme ketika anak berusia sekitar tiga tahun

Responden ketiga yaitu responden MS, memiliki dua orang anak laki-laki, dimana anak kedua dari responden MS mengalami gangguan autisme. Anak responden MS didiagnosa mengalami gangguan autisme ketika anak berusia sekitar dua tahun dan saat ini anak responden berusia tujuh tahun.

\section{Tempat Penelitian}

Penelitian dilaksanakan di tempat yang telah disepakati antara responden dan peneliti. Penelitian dilakukan di wilayah Kota Denpasar. Lokasi pengambilan data penelitian dilakukan di Kota Denpasar karena ketiga responden yang berpartisipasi dalam penelitian ini berdomisili di sekitar Kota Denpasar.
Wawancara

Penelitian ini menggunakan metode wawancara semiterstruktur dengan jenis wawancara yang termasuk ke dalam kategori indepth interview. Isi dari wawancara dalam penelitian bertujuan untuk mengungkapkan aspek tingkah laku mengenai apa yang dilakukan atau biasa dilakukan oleh responden; pemahaman dan interpretasi responden mengenai pemikiran, tujuan, harapan, dan nilai-nilai yang dimiliki responden; perasaan serta pemahaman responden tentang aspek afektif dalam diri responden seperti respon emosional responden terhadap pengalaman dan pemikiran responden sebagai ibu yang memiliki anak dengan gangguan autisme.

Observasi

Penelitian ini menggunakan jenis observasi non-partisipan dan terbuka. Observasi yang dilakukan berlokasi di tempat dan hari yang sama dengan pelaksanaan wawancara. Fokus penelitian diarahkan pada aspek khusus yaitu respon nonverbal yang tercermin dalam perilaku, sikap, dan ekspresi wajah yang ditampilkan oleh responden selama proses wawancara berlangsung serta intonasi yang digunakan pada kata-kata yang diucapkan oleh responden. Selain itu juga dilakukan pengamatan terhadap interaksi responden dengan anak responden baik sebelum dan sesudah proses wawancara berlangsung, interaksi responden dengan terapis, serta beberapa orang lain yang berada di sekitar responden selama wawancara berlangsung. Observasi ini dilakukan untuk mendapatkan informasi terkait gambaran emosi dan sikap responden, gambaran interaksi responden dengan anak responden yang mengalami gangguan autisme, gambaran interaksi responden dengan terapis, dan gambaran interaksi responden dengan orang-orang disekitar responden.

Laporan diri responden

Laporan diri responden yang dimaksud di dalam penelitian ini adalah responden diminta untuk melaporkan data berupa tulisan deskriptif mengenai pengalaman responden yang memiliki anak dengan gangguan autisme pada angket yang telah diberikan oleh peneliti. Laporan diri responden bertujuan untuk menggali informasi mengenai diri responden, untuk mengantisipasi adanya hal-hal yang penting mengenai diri responden yang sulit untuk disampaikan dalam proses wawancara, serta untuk mengklarifikasi kembali informasi yang telah disampaikan responden pada saat wawancara.

\section{Teknik Analisis Data}

Penelitian ini menggunakan teknik analisis data theoretical coding yang terdiri dari open coding, axial coding, dan selective coding (Strauss \& Corbin, 2017). Open coding adalah proses menguraikan, memeriksa, membandingkan, mengonsepkan, dan mengategorikan data. Tahap kedua adalah axial coding. Axial coding seperangkat prosedur dimana data digabungkan kembali dengan cara baru setelah dilakukannya open coding dengan membuat hubungan antar kategori. Tahap terakhir adalah selective coding merupakan proses pemilihan kategori inti, pengaitan kategori inti terhadap kategori lainnya secara sistematis, pengabsahan hubungannya, mengganti kategori yang diperbaiki, dan dikembangkan lebih lanjut.

\section{Teknik Penggalian Data}




\section{HASIL PENELITIAN}

Hasil dari penelitian ini akan dipaparkan berdasarkan lima kategori antara lain diagnosa autisme, krisis-krisis yang dialami oleh ibu dengan anak autisme, tindakan untuk mencapai resiliensi diri, faktor-faktor yang memengaruhi tindakan untuk mencapai resiliensi diri, dan kondisi setelah tindakan.

\section{Diagnose Autisme}

Perkembangan Anak Menunjukkan Perilaku yang Menimbulkan Kecurigaan

Perkembangan anak yang pada awalnya tampak normal, mulai menunjukkan perbedaan dan keterlambatan apabila dibandingkan dengan anak pada umumnya. Berdasarkan hasil wawancara terdapat beberapa perilaku pada anak yang tidak sesuai dengan perilaku yang ditampilkan oleh anak pada umumnya, diantaranya keterlambatan perkembangan, asik dengan dunia sendiri, tantrum, hand flipping, cara bermain berbeda atau tidak sesuai, dan penurunan kemampuan (regresi). Respon Ibu Terhadap Perilaku Anak yang Mencurigakan Pada awalnya responden mengatakan bahwa tidak menyadari perilaku-perilaku tersebut dan tidak berfikir bahwa anaknya mengalami gangguan. Responden tidak menaruh perhatian khusus pada perkembangan yang ditunjukkan oleh anak, yang sebenarnya sudah menunjukkan ciri-ciri gangguan autisme melainkan menganggap keterlambatan yang dialami oleh anak adalah keterlambatan biasa.

\section{Perilaku Mencari Pengobatan}

Perilaku mencari pengobatan dimana responden membawa anak ke dokter anak atau psikiater agar memeroleh penanganan yang tepat. Berdasarkan hasil wawancara, pengobatan yang dilakukan oleh responden dibagi menjadi dua yaitu pengobatan medis dengan membawa anak ke dokter spesialis anak dan psikiater; dan pengobatan non-medis.

\section{Karakteristik Anak dengan Gangguan Autisme}

Karakteristik anak dengan autisme akan dibagi ke dalam dua bagian antara lain social-communication dan behavior. Social Communication, anak mengembangkan komunikasi yang bersifat satu arah, menggunakan kalimat pendek dengan kosa kata sederhana cenderung terbatas dan sulit dipahami, tidak adanya kontak mata pada saat berkomunikasi serta belum mampu mengekspresikan emosi dengan tepat. Anak dengan autisme memiliki hendaya dalam mengembangkan dan mempertahankan hubungan dengan teman sebaya.

Behavior, anak dengan autisme memiliki pola aktivitas yang repetitif, sulit untuk menerima perubahan, pola pikir yang kaku, dan munculnya ekolalia. Ketertarikan kuat pada suatu objek secara berlebihan yang tidak biasa dan hiperaktivitas pada input sensori.

\section{Krisis-Krisis yang Dialami Ibu dengan Anak Autisme Krisis Internal}

Krisis-krisis internal yang dialami oleh responden mencakup kondisi psikologis responden yaitu reaksi responden pasca anak didiagnosa mengalami gangguan autis. Berdasarkan hasil wawancara diketahui bahwa responden merasa terkejut mendengar hasil diagnosa karena tidak pernah terpikirkan sebelumnya bila anak responden mengalami gangguan autisme. Reaksi tersebut diikuti dengan perasaan tidak percaya dan tidak menerima hasil diagnosa tersebut pada diri responden.

Kurangnya pengetahuan mengenai apa itu gangguan autisme, memunculkan kebingungan pada diri responden sehingga muncul pertanyaan-pertanyaan antara lain: mengapa anak bisa mengalami gangguan autisme, apa penyebab gangguan autisme, apakah anak bisa sembuh, dan bagaimana menangani anak dengan gangguan autisme. Selain itu, muncul juga perasaan cemas pada diri responden apakah gangguan yang dialami oleh anak juga akan dialami pada kehamilan selanjutnya, sehingga responden memutuskan untuk menunda kehamilan

Responden juga merasakan perasaan sedih yang mendalam terkait gangguan yang dialami oleh anaknya pasca mendengarkan hasil diagnosis. Ketidakmampuan anak berkomunikasi dan mengembangkann interaksi sosial yang bermakna dengan lingkungan sekitar juga menyebabkan responden merasa sedih.

$\underline{\text { Krisis Eksternal }}$

Krisis eksternal yang dimaksudkan di dalam penelitian ini adalah krisis yang berasal dari luar diri responden yang dialami responden sebagai ibu dengan anak autisme. Krisis eksternal pertama adalah beban finansial. Kehadiran anak dengan gangguan autisme di tengah-tengah keluarga menyebabkan responden harus mengerahkan seluruh perhatian dan memberikan pengawasan yang penuh, sehingga responden harus berhenti bekerja. Hal tersebut menyebabkan pemasukan responden berkurang sedangkan pengeluaran untuk memenuhi kebutuhan anak dengan autisme bertambah.

Krisis eksternal kedua adalah konflik peran ganda. Sebagai seorang ibu, responden dituntut untuk menjalankan peran ganda yaitu menjalankan tugas pengasuhan dan mengerjakan tugas sebagai ibu rumah tangga. Konflik peran terjadi ketika salah satu peran menuntut perhatian yang lebih banyak. Dalam hal ini responden dituntut untuk memberikan perhatian dan pengawasan penuh bagi anak dengan gangguan autisme karena kurangnya kemandirian pada anak dengan autisme.

Krisis eksternal ketiga adalah kondisi anak dengan gangguan autisme. Responden kerap tidak dapat mengerti keinginan anak karena disabilitas yang dimiliki anak menyebabkan anak sulit mengembangkan kemampuan komunikasi dan interaksi sosial yang bermakna. Ketidakmampuan responden dalam memahami keinginan anak dapat memicu munculnya perilaku tantrum pada anak. Selain itu responden juga dituntut untuk mempersiapkan anak memasuki masa pubertas. Hal ini menjadi krisis bagi responden karena kondisi anak yang belum mandiri sehingga harus dibantu oleh responden.

Krisis eksternal keempat adalah penerapan diet. Terdapat beberapa hambatan yang ditemui oleh responden dalam menerapkan diet sehingga muncul inkonsistensi dalam penerapan diet. Hambatan berasal dari diri responden, lingkungan eksternal, dan diri anak. 
Krisis eksternal kelima adalah proses terapi. Kebijakan tempat terapi terkait pembebasan biaya terapi menimbulkan permasalahan tersendiri bagi responden dimana responden merasa cemas terkait proses terapi sehingga muncul pertanyaan apakah anak diajari dengan benar selama proses terapi. Selain itu muncul kekhawatiran responden terkait kualitas terapis mengingat tidak semua terapis latar belakang pendidikan yang sesuai. Tidak dikenakannya biaya berdampak pada pengurangan jumlah jam terapi, yang kemudian berdampak pada perkembangan anak yang pada awalnya menunjukkan perkembangan yang baik kemudian mengalami penurunan. Hal ini menjadi krisis bagi responden dalam tugas pengasuhan anak, sehingga intensitas pengajaran yang dilakukan responden ketika berada di rumah harus ditingkatkan untuk meminimalisir penurunan perkembangan pada anak.

Krisis eksternal keenam adalah respon lingkungan sekitar. Responden mengatakan bahwa dirinya dan anak kerap mendapatkan respon negatif dari lingkungan sekitar diantaranya persepsi keliru mengenai anak dengan autisme, penolakan kehadiran anak, bullying, cara pandang aneh, dan anak menjadi pusat perhatian terutama ketika berada di area publik.

Dampak Krisis Internal dan Eksternal yang Dialami Ibu dengan Anak Autisme

Krisis-krisis yang dialami oleh responden baik itu krisis internal maupun krisis eksternal tentu berdampak pada diri responden, diantaranya berdampak pada kondisi fisik dan psikis, berdampak pada aktivitas sehari-hari, dan berdampak pula pada interaksi sosial responden yang kemudian memicu timbulnya konflik di dalam keluarga.

\section{Tindakan untuk Mencapai Resiliensi Diri}

\section{Mengembangkan Mekanisme Penyesuaian Diri}

Mekanisme penyesuaian diri dibagi ke dalam sub bagian yaitu mekanisme penyesuaian diri terhadap karakteristik anak dan mekanisme penyesuaian diri terhadap respon lingkungan sekitar. Mekanisme penyesuaian diri terhadap karakteristik anak yang dimaksud di dalam penelitian ini adalah cara yang dilakukan oleh responden untuk dapat menyesuaikan dirinya terhadap keadaan anak yang mengalami gangguan autisme. Hal ini dilakukan dengan cara menumbuhkan pandangan positif terhadap kehadiran anak dan mengupayakan penanganan sesuai kebutuhan anak meliputi mengikutsertakan anak pendidikan inklusi, melatih anak di rumah, dan menerapkan diet.

Mekanisme penyesuaian diri juga dilakukan responden dengan respon lingkungan sekitar terhadap kondisi anak responden yang mengalami gangguan autisme. Hal ini dilakukan dengan cara memberikan penjelasan kepada lingkungan sekitar terkait kondisi anak dan bersikap selektif terhadap respon lingkungan sekitar.

Mengembangkan Mekanisme Koping

Dalam menghadapi berbagai krisis baik krisis internal maupun krisis eksternal sebagai ibu dengan anak autisme, diperlukan cara untuk dapat mengatasi stres dan hambatan-hambatan yang dialami dengan mengembangkan mekanisme koping. Mekanisme koping yang dikembangkan oleh responden dibagi ke dalam dua kategori yaitu emotional focused coping dan problem focused coping.
Emotional focused coping merupakan strategi koping yang digunakan untuk untuk mengatur dan mengendalikan respon emosi terhadap stres yang dialami. Strategi pertama adalah kontrol diri. Kontrol diri adalah koping yang digunakan responden untuk mengatur emosi negatif yang dirasakan sebagai dampak dari suatu masalah. Ketika muncul suatu masalah, responden berusaha untuk mengontrol perilaku dalam memberikan respon terhadap masalah tersebut. Selain melakukan kontrol terhadap perilaku, responden juga melakukan kontrol terhadap pikirian dalam bentuk berfikir positif.

Strategi kedua adalah berpasrah. Saat menghadapi masalah responden mendekatkan diri dengan Tuhan melalui berdoa dan berpasrah pada kehendak Tuhan serta ikhlas menerima pemberian Tuhan.

Strategi ketiga adalah melakukan pengalihan. Strategi yang dilakukan oleh responden dalam mereduksi stres yang dirasakan adalah dengan melakukan pengalihan yaitu aktif berkegiatan di luar rumah. Kegiatan yang diikuti oleh responden dilakukan setelah menyelesaikan pekerjaan responden di rumah. Melalui kegiatan yang diikuti, responden memeroleh dampak positif seperti perasaan yang lebih tenang dan lebih bersemangat.

Problem focused coping merupakan strategi koping yang berfokus pada masalah yang dihadapi. Strategi pertama adalah pencarian informasi yang dilakukan dengan aktif mengikuti seminar parenting dan menjalin kerjasama dengan terapis yang menangani anak.

Strategi kedua adalah pencarian bantuan. Krisis dalam menjalani peran ganda menyebabkan responden mengalami kelelahan dan perasaan tidak mampu untuk menyelesaikan semua tugas sehingga responden memutuskan untuk mencari bantuan dalam menyelesaikan tugasnya.

Strategi ketiga adalah pemecahan masalah bersama. Permasalahan yang muncul antara responden dengan suami diselesaikan bersama-sama melalui komunikasi.

\section{Faktor-Faktor yang Memengaruhi Tindakan untuk Mencapai Resiliensi Diri}

Faktor Internal

Faktor internal yang dimaksud dalam penelitian ini adalah faktor-faktor yang berasal dari dalam diri individu sehingga individu melakukan tindakan penyesuaian diri dan koping untuk mencapai resiliensi diri. Faktor internal pertama adalah religiusitas. Kehadiran anak dengan autisme membuat responden semakin mendekatkan diri dengan Tuhan.

Faktor internal kedua adalah kemampuan dalam mengekspresikan pikiran dan perasaan. Kemampuan responden dalam mengekspresikan pikiran dan perasaan yang dimaksud dalam penelitian ini adalah responden mampu bercerita mengenai apa yang dialami dan dirasakan dengan sesama orangtua yang memiliki anak dengan autisme. Dengan bercerita dan sharing dengan sesama orangtua dengan anak autisme, 
responden merasa lebih ringan karena sudah mengeluarkan emosi-emosi negatifnya.

Faktor internal ketiga adalah harapan. Harapan yang dimiliki oleh responden menimbulkan motivasi bagi responden dalam menjalani kehidupannya dan memberikan pengasuhan yang optimal bagi anak.

\section{Faktor Eksternal}

Faktor eksternal adalah faktor-faktor yang berasal dari luar diri responden yang membantu responden mencapai resiliensi diri yang positif. Faktor eksternal pertama adalah dukungan sosial. Dukungan sosial diperoleh responden dari pasangan, keluarga, terapis, sesama orangtua dengan anak autisme, dan lingkungan sekitar.

Faktor eksternal kedua adalah perkembangan kondisi anak. Perkembangan kondisi anak yang semakin menunjukkan kemajuan menjadi semangat bagi responden dalam memberikan pengasuhan bagi anak dan membantu responden mengatasi emosi negatif.

Faktor eksternal ketiga adalah pengalaman orang lain. Melalui pengalaman sesama orangtua dengan anak autisme, responden dapat termotivasi dalam memberikan pengasuhan yang optimal bagi anak serta tidak merasa sendiri menghadapi permasalahan tersebut.

Faktor eksternal keempat adalah lama waktu pengasuhan. Responden mengatakan bahwa setelah sekian lama mengasuh anak, dimana responden penelitian ini sudah mengasuh anak dengan gangguan autisme sekitar 5 tahun - 11 tahun pasca anak didiagnosis mengalami autisme, sehingga responden sudah terbiasa dalam mengasuh anak dengan autisme dan mengatasi permasalahan yang muncul.

\section{Kondisi Setelah Tindakan}

Berdasarkan hasil wawancara dapat diketahui bahwa responden telah mampu menerima kondisi anak yang mengalami gangguan autisme dan mencapai resiliensi diri yang positif, dimana responden telah mampu meregulasi emosi baik saat mengasuh anak dengan gangguan autisme maupun saat menanggapi respon lingkungan sekitar, mampu mengendalikan keinginan, memiliki keyakinan akan kemampuan diri, berempati, dan mampu mengambil hikmah dari permasalahan yang dihadapi.

\section{Reseliensi Ibu dengan Anak Autisme}

Hasil diagnosa yang menyatakan bahwa anak mengalami gangguan autisme menimbulkan kondisi yang menekan bagi responden. Sebagai seorang ibu dengan anak autisme, responden dihadapkan pada tanggung jawab yang lebih besar untuk mengasuh anak dengan autisme yang memiliki karakteristik yang berbeda dengan anak pada umumnya. Kondisi tersebut memunculkan krisis-krisis bagi responden. Krisis-krisis yang dimaksud meliputi krisis internal dan krisis eksternal. Krisis internal yang dialami responden antara lain perasaan terkejut, tidak percaya dan tidak menerima hasil diagnosis, munculnya kebingungan karena kurangnya pengetahuan dan pengalaman dalam mengasuh anak dengan autisme, perasaan cemas, perasaan sedih, dan perasaan malu yang membuat responden menutup diri terkait kondisi anak. Krisis eksternal yang dialami responden antara lain beban finansial, konflik peran ganda, kondisi anak, penerapan diet, proses terapi yang dijalani oleh anak, dan respon lingkungan sekitar yang bersifat negatif. Krisis internal dan krisis eksternal yang dialami oleh responden kemudian akan berdampak pada kondisi fisik dan psikis, aktivitas sehari-hari, dan interaksi sosial responden yang kemudian memicu timbulnya konflik di dalam keluarga.

Krisis-krisis yang dialami oleh responden memerlukan serangkaian tindakan aktif yang mampu mengurangi dampak dari krisis-krisis yang muncul sebagai ibu dengan anak autisme. Tindakan aktif yang dilakukan oleh responden yaitu mekanisme penyesuaian diri dan mekanisme koping. Mekanisme penyesuain diri dibagi menjadi dua, yaitu penyesuaian diri terhadap karakteristik anak dan terhadap respon lingkungan sekitar.

Mekanisme koping yang dikembangkan oleh responden antara lain emotional focused coping dan problem focused coping. Emotional focused coping meliputi kontrol diri, berpasrah, diam dan menghindar, serta aktif berkegiatan. Problem focused coping meliputi pencarian informasi, pencarian bantuan, dan komunikasi.

Selain itu, terdapat beberapa faktor yang menjadi alasan responden untuk terus berusaha menyesuaikan diri dan mengembangkan mekanisme koping yang adaptif, faktor tersebut dibagi menjadi dua yaitu faktor internal dan faktor eksternal. Faktor internal meliputi religiusitas, kemampuan dalam mengekspresikan pikiran dan perasaan, dan harapan. Faktor eksternal meliputi dukungan sosial, perkembangan kondisi anak, pengalaman orang lain, dan lama waktu pengasuhan.

Tindakan aktif yang dilakukan oleh responden dan beberapa faktor yang memengaruhi tindakan aktif tersebut berpengaruh pada kondisi responden saat ini, dimana responden telah mencapai resiliensi diri. Responden yang telah beresilien mampu meregulasi emosi baik saat mengasuh anak dengan gangguan autisme maupun saat menanggapi respon lingkungan sekitar, mampu mengendalikan keinginan, memiliki keyakinan akan kemampuan diri, berempati, dan mampu mengambil hikmah dari permasalahan yang dihadapi.

\section{PEMBAHASAN DAN KESIMPULAN}

Berdasarkan hasil wawancara yang telah dilakukan, peneliti menemukan bahwa kehadiran anak dengan gangguan autisme di tengah-tengah keluarga menimbulkan kondisi yang menekan terutama bagi seorang ibu. Benderix, Nordstrom, \& Sivberg (2006) menemukan bahwa orangtua dengan anak autisme menunjukkan level stres yang tinggi. Ibu dihadapkan pada tanggung jawab yang lebih besar dalam tugas pengasuhan anak dengan autisme yang tentunya memiliki karakteristik berbeda dengan anak pada umumnya. Beberapa karakteristik yang ditunjukkan oleh anak dengan autisme antara lain ketidakmampuan dalam mengembangkan komunikasi yang 
bersifat dua arah, penggunaan kosa kata sederhana yang cenderung sulit untuk dipahami, tidak adanya kontak mata ketika diajak berkomunikasi, ketidakmampuan dalam menampilkan emosi secara tepat, kesulitan untuk membangun pertemanan dan tidak adanya ketertarikan dengan teman sebaya, pola aktivitas yang repetitif, ketertarikan yang kuat pada suatu objek, dan hiperaktivitas pada input sensori. Hal tersebut sesuai dengan kriteria diagnosa gangguan autisme pada DSM-V (APA, 2013) yang membagi karakteristik dan hendaya pada gangguan autisme ke dalam dua kriteria yaitu, sosial komunikasi dan tingkah laku.

Kondisi tersebut memunculkan krisis bagi responden. Krisis yang dialami oleh responden dibagi ke dalam dua bagian, yaitu krisis internal dan krisis eksternal. Krisis internal yang dialami oleh responden meliputi perasaan terkejut, tidak percaya dan cenderung tidak menerima hasil diagnosa, munculnya kebingungan, perasaan cemas, perasaan sedih, dan perasaan malu sehingga cenderung untuk menutup diri dari lingkungan sosial. Lord \& McGee (2001) mengungkapkan bahwa orangtua dengan anak autisme menghadapi kesedihan, kemarahan, kekecewaan, emosi kompleks lainnya ketika mengetahui bahwa anak mengalami permasalahan perkembangan yang siginifikan dan secara terus menerus berkorban untuk melayani dan memenuhi kebutuhan anak. Selain itu ibu dengan anak autisme dihadapkan pada kekhawatiran diantaranya kesejahteraan anak di masa depan, kemampuan anak untuk dapat berfungsi secara mandiri, dan penerimaan lingkungan sekitar terhadap kehadiran anak dengan autisme (Lord \& McGee, 2001).

Sedangkan krisis eksternal yang dialami oleh responden yang ditemukan dalam penelitian ini meliputi beban finansial, konflik peran ganda, kondisi anak dengan gangguan autisme, penerapan diet, proses terapi, dan respon lingkungan sekitar terutama respon yang bersifat negatif.

Krisis eksternal pertama adalah beban finansial. Beban finansial yang dimaksud adalah biaya yang harus dikeluarkan responden untuk memenuhi kebutuhan anak dengan autisme akan pendidikan yang tidak sedikit. Menurut Zager (2005) kesulitan keuangan terkait dengan membesarkan anak yang dihadapi oleh keluarga pada umumnya, seringkali lebih intens dan berlangsung secara berkelanjutan pada keluarga yang memiliki anak dengan gangguan autisme. Pengasuhan secara penuh yang diperlukan oleh anak menyebabkan responden tidak bisa melanjutkan pekerjaan sehingga tidak memeroleh penghasilan tambahan. Beban secara ekonomi dalam membesarkan anak yang mengalami autisme merupakan stres yang dialami oleh orangtua yang memiliki anak autis, yang kemudian berdampak pada karir orangtua ataupun penghasilan (Jarbrink, Fombonne, \& Knapp, 2003).

Krisis eksternal kedua adalah konflik peran ganda. Konflik peran ganda yang dimaksud dalam penelitian ini adalah peran ganda yang harus diemban oleh responden, dimana responden harus memberikan pengasuhan bagi anak dengan autisme sekaligus menjalankan kewajiban sebagai ibu rumah tangga. Susanto (2010) mengatakan bahwa konflik peran ganda sering terjadi ketika salah satu dari peran tersebut menuntut lebih banyak perhatian, sehingga tuntutan peran lain tidak bisa dipenuhi secara optimal.

Krisis eksternal ketiga yaitu kondisi anak dengan gangguan autisme. Krisis yang dihadapi responden dalam mengasuh anak dengan autisme disebabkan oleh keterbatasan anak dalam berkomunikasi. Ketidakmampuan anak dalam menyampaikan keinginan secara terarah membuat responden sulit untuk dapat memahami sehingga memicu timbulnya perilaku tantrum pada anak dengan autisme (Mansur, 2016). Perilaku yang tidak terkendali pada anak dengan autisme yang mengamuk tanpa ada sebab yang jelas, yang bisa muncul kapan dan dimana saja, yang menyebabkan orangtua kehilangan kesabaran, marah, jengkel, dan sedih. Perasaan ini berlangsung secara terus menerus, sehingga orangtua merasa kelelahan dan sangat stres menghadapi kondisi anak tersebut (Susilowati, 2007).

Dalam penelitian ini ditemukan bahwa responden dengan anak autisme yang berjenis kelamin perempuan menghadapi permasalahan saat anak akan memasuki masa pubertas. Responden melaporkan ketidaksiapan ketika menyadari bahwa anak akan memasuki masa pubertas, karena kondisi yang dialami oleh anak dan tingkat kemandirian yang masih kurang. Gabriels \& Hill (2007) menyatakan bahwa mengajarkan seksualitas pada anak dapat menjadi sebuah tantangan terlebih pada anak yang mengalami gangguan autisme karena gangguan yang dialami.

Krisis eksternal keempat yaitu penerapan diet. Penerapan diet pada anak dengan autisme dapat menjadi salah satu sumber stres bagi ibu. Dalam penelitian ini terdapat tiga hambatan dalam menerapkan diet pada anak dengan autisme.

Pertama, hambatan yang berasal dari responden meliputi perasaan kasihan yang dirasakan oleh responden karena penerapan diet berdampak pada status gizi dan kondisi fisik tubuh anak, dikarenakan penerapan diet secara tidak langsung akan mengurangi pemasukan vitamin, mineral, dan zat lain yang dimiliki oleh sumber makanan tersebut (Puspitha \& Berawi, 2016). Keterbatasan akan sedikitnya variasi makanan yang tidak mengandung gluten dan kasein menjadi salah satu masalah yang harus dihadapi orangtua dalam penerapan diet bagi anak dengan autisme (Ramadayanti \& Margawati, 2013) menyebabkan responden kebingungan ketika harus menyiapkan makanan bagi anak.

Kedua, hambatan yang berasal dari lingkungan eksternal yaitu ketidakmampuan responden untuk mengontrol lingkungan eksternal. Ramadayanti \& Margawati (2013) juga mengungkapkan bahwa keberhasilan penerapan diet pada anak autis sangat dipengaruhi oleh lingkungan. Responden kesulitan untuk melarang anak memilih makanan ketika anak diajak pergi ke swalayan, karena akan memicu timbulnya perilaku tantrum pada anak. Sesuai dengan pernyataan Ramadayanti \& Margawati (2013) bahwa anak dengan autis masih tergolong mudah dalam mengakses makanan yang mengandung gluten maupun kasein baik yang tersedia di mini market, kantin sekolah, maupun toko makanan di lingkungan rumah. Selain itu, adanya kemungkinan bagi anak untuk meniru pola makan dari lingkungan terdekat yaitu keluarga. Hal tersebut disebabkan karena oranglain dilingkungan anak akan menjadi 
role model bagi anak dan anak akan mengamati serta meniru apa yang dilihat (Sofia, Ropi, \& Mardhiyah, 2012).

Ketiga, penolakan penerapan diet yang berasal dari anak sendiri. Ramadayanti \& Margawati (2013) mengatakan bahwa hambatan dalam menerapkan diet dapat terjadi karena adanya perilaku tantrum dan picky eaters yang muncul pada anak sehingga membuat orangtua mengalah karena tidak tega.

Krisis eksternal selanjutnya adalah proses terapi. Proses terapi yang diikuti oleh anak dengan gangguan autisme juga dapat menjadi sumber krisis bagi ibu. Dalam penelitian ini ditemukan bahwa berkurangnya jumlah jam terapi yang diikuti oleh anak dan kekhawatiran responden terhadap kualitas dari terapis yang menangani anak menimbulkan kecemasan bagi responden. Sesuai dengan yang diungkapkan oleh Lord \& McGee (2001) bahwa pendidikan anak dengan autisme dapat menjadi sumber stres yang signifikan bagi beberapa keluarga.

Krisis eksternal yang terakhir adalah respon lingkungan sekitar yang bersifat negatif. Dalam penelitian ini ditemukan bahwa respon lingkungan sekitar terutama yang bersifat negatif dapat menimbulkan stres bagi responden. Respon lingkungan terhadap kondisi gangguan yang dialami oleh anak, membuat responden merasa sedih dan tidak jarang membuat responden marah. Hasil penelitian Suraiya \& Astuti (2008) juga menunjukkan bahwa perilaku atau tanggapan di lingkungan juga merupakan salah satu faktor stres bagi orangtua yang dapat membuat orangtua merasa tertekan.

Krisis-krisis yang dialami oleh responden berdampak pada kondisi fisik dan psikis, aktivitas sehari-hari, dan interaksi sosial responden, yang kemudian memicu timbulnya konflik di dalam keluarga. Dalam memenuhi kewajiban melaksanakan peran ganda, responden melaporkan adanya kelelahan secara fisik dan psikis dimana responden menjadi mudah lelah dan mudah untuk merasakan emosi negatif. Hasil penelitian Harta (2015) menunjukkan bahwa sumber stres utama bagi orangtua yang memiliki anak autis adalah kondisi anak yang mengharuskan orangtua untuk menjaga selama 24 jam, sehingga menimbulkan kelelahan fisik dan emosional.

Krisis berpengaruh pada aktivitas sehari-hari responden, diantaranya responden harus berhenti bekerja, penundaan penyelesain pekerjaan rumah tangga, dan keterbatasan untuk terlibat secara aktif dalam kegiatan-kegiatan di lingkungan sekitar. Hal tersebut memicu timbulnya stres pada responden. Secara umum, ibu melaporkan lebih banyak stres daripada ayah yang berkaitan dengan masalah tuntutan waktu dan pengorbanan diri dalam mengasuh anak dengan autisme (Lord \& McGee, 2001).

Interaksi sosial ibu juga dipengaruhi oleh hadirnya anak dengan autisme. Mayoritas orangtua yang memiliki anak dengan autisme memilih untuk menutup diri pada lingkungan sekitar karena takut akan adanya penolakan (Wulandari, 2017). Dalam penelitian ini ditemukan bahwa responden cenderung membatasi interaksinya dengan lingkungan sekitar karena malu dan merasa sungkan karena perilaku yang ditunjukkan oleh anak.
Stres yang dialami oleh responden akibat kelelahan, terganggunya aktivitas sehari-hari, dan terganggunya interaksi dengan lingungan sosial menjadi salah satu pencetus munculnya konflik di dalam keluarga, yaitu konflik antara responden dengan suami. Disabilitas pada anak dan kebutuhan anak akan perhatian dan pengasuhan dengan intensitas yang besar serta kecenderungan orangtua terhadap isolasi, kecemasan kronis, dan stres yang timbul karena berkurangnya otonomi, yang dapat berkontribusi meningkatkan risiko ketidakseimbangan di dalam keluarga (Vigilante dalam Zager, 2005).

Untuk dapat menjadi individu yang beresilien, ibu perlu beradaptasi dalam menghadapi dan mengatasi krisis-krisis yang dialami. Reich, Zautra, \& Hall (2010) mengungkapkan bahwa resiliensi didefinisikan sebagai hasil adaptasi yang sukses terhadap kesulitan. Dalam penelitian ini diketahui bahwa untuk dapat menghadapi dan mengatasi krisis-krisis yang dialami sehari-hari, responden mengembangkan mekanisme penyesuaian diri dan mekanisme koping.

Mekanisme penyesuaian diri yang dikembangkan oleh responden dibagi menjadi dua yaitu mekanisme penyesuaian diri terhadap karakteristik anak dan penyesuaian diri terhadap respon lingkungan sekitar. Penyesuaian diri terhadap karakteristik anak dikembangkan oleh responden yaitu dengan menumbuhkan pandangan positif terhadap anak dan mengupayakan penanganan sesuai kebutuhan anak. Menumbuhkan pandangan positif terhadap kehadiran anak, dimana responden melihat bahwa anak adalah titipan dari Tuhan yang harus diterima dengan segala kelebihan maupun kekurangan yang dimiliki oleh anak dan tidak melihat kehadiran anak sebagai beban. Persepsi positif yang dimiliki orangtua dengan ABK dapat meningkatkan kualitas hidup mereka menjadi lebih baik sehingga penyesuaian mereka terhadap anak tentu akan baik (Gupta \& Singhal, 2004).

Mekanisme penyesuaian diri yang kedua adalah melakukan berbagai upaya untuk dapat mengoptimalkan perkembangan anak dengan autisme. Hallahan, Kauffman, \& Pullen (2009) mengungkapkan upaya awal yang dapat dilakukan oleh orangtua untuk anak yang baru didiagnosis mengalami kebutuhan khusus yaitu mencari penanganan sesuai yang dapat diberikan untuk anak, agar prevalensi anak untuk tumbuh dan berkembang kearah yang lebih baik semakain tinggi. Dalam penelitian ini ditemukan tiga upaya yang dilakukan oleh responden yaitu mengikutsertakan anak pada pendidikan inklusi, memberikan pengasuhan dan pelatihan anak di rumah, dan menerapkan diet pada anak.

Kondisi lingkungan yang mendukung akan memberikan hal positif untuk orangtua dalam proses penyesuaian dirinya, dimana hal ini dapat menjadi motivasi bagi orangtua (Wahyuni, 2011). Faktanya, dalam penelitian ini ditemukan bahwa adanya respon negatif dari lingkungan yang menyebabkan munculnya emosi negatif dalam diri responden. Walaupun orangtua sudah mampu beradaptasi dengan keadaan anak, penolakan lingkungan sekitar terhadap kehadiran anak dengan autisme membuat orangtua merasa sedih, malu, bahkan tertekan dengan 
keadaan tersebut sehingga cenderung menyembunyikan anak dari lingkungan sekitar (Istiqamah, 2012). Hal inilah yang menuntut responden untuk dapat menyesuaikan diri dengan respon lingkungan terutama yang bersifat negatif. Mekanisme penyesuaian diri terhadap respon lingkungan sekitar yang dilakukan oleh responden yang ditemukan di dalam penelitian ini antara lain dengan memberikan penjelasan kepada lingkungan sekitar terkait gangguan yang dialami oleh anak. Menjelaskan kondisi anak dengan autisme kepada lingkungan merupakan salah satu cara agar lingkungan tidak menganggap anak dengan autisme berbeda dan membuat lingkungan pada akhirnya bisa menerima keberadaan anak dengan autisme (Rufaidah, 2014). Selain itu responden juga bersikap selektif dengan hanya menanggapi dan menerima saran yang bersifat positif serta mengabaikan respon yang bersifat negatif. Sikap selektif yang ditunjukkan oleh responden sejalan dengan salah satu strategi regulasi emosi yang diungkapkan Gross (2014) yaitu pemilihan situasi, dimana strategi ini individu dapat menentukan tindakan yang dilakukan seperti mendekati atau menghindari orang, tempat, atau objek berdasarkan dampak emosi yang muncul, untuk mengurangi timbulnya emosi negatif seperti perasaan sedih atau marah.

Selain mengembangkan penyesuaian diri, krisis-krisis yang dialami oleh responden juga menuntut responden untuk dapat mengembangkan mekanisme koping yang adaptif terhadap krisis-krisis yang dialami. Resiliensi juga berkaitan dengan koping terhadap stres (Kitano \& Lewis; Werner dalam Embury \& Saklofske, 2013). Koping adalah suatu proses dimana individu mencoba untuk mengelola ketidaksesuain yang dirasakan antara tuntutan dan sumber daya yang dinilai dalam situasi yang menekan (Sarafino \& Smith, 2011). Menurut Lazarus \& Folkman (1984) koping memiliki dua fungsi utama yaitu dapat mengubah permasalahan yang menyebabkan munculnya stres atau dapat mengatur respon emosional terhadap masalah.

Berdasarkan penelitian yang telah dilakukan, mekanisme koping yang dikembangkan oleh responden dibagi ke dalam bentuk, yaitu emotional focused coping dan problem focused coping. Emotional Focused Coping dibagi ke dalam empat strategi koping, antara lain kontrol diri (self-control), berpasrah, dan melakukan pengalihan. Sedangkan Problem Focused Coping dibagi ke dalam tiga strategi koping, antara lain pencarian informasi, pencarian bantuan, dan pemecahan masalah bersama. Strategi koping yang dikembangkan responden sesuai dengan strategi koping yang dipaparkan oleh Lazarus \& Folkman (1984) dimana koping dibagi menjadi dua strategi, yaitu Emotional Focused Coping dan Problem Focused Coping.

Emotional Focused Coping adalah strategi koping yang berorientasi untuk mengurangi reaksi emosi negatif, sedangkan Problem Focused Coping strategi koping yang berorientasi pada penyelesaian masalah. Emotional focused coping dibagi menjadi tiga strategi koping yaitu kontrol diri, berpasrah, dan melakukan pengalihan. Sedangkan problem focused coping dibagi menjadi tiga strategi koping yaitu pencarian informasi, pencarian bantuan, dan pemecahan masalah bersama. Keenam strategi koping ini akan dijelaskan kemudian.
Kontrol diri merupakan strategi koping yang digunakan oleh responden dalam mengendalikan perilaku dan pikiran terhadap emosi negatif yang timbul dari permasalahan. Menurut Lazarus \& Folkman (1984) kontrol diri adalah usaha yang dilakukan untuk meregulasi perasaan atau tindakan terhadap suatu permasalahan. Responden melakukan kontrol diri dengan cara mengatur perilaku dan pikirannya. Sarafino \& Smith (2011) membagi kontrol ke dalam dua kategori, yaitu kontrol perilaku dan kontrol kognitif. Dengan adanya kontrol pada diri, responden dapat mengontrol perilakunya dan mengendalikan emosi negatif yang timbul dari krisis yang dihadapi sebagai ibu dengan anak autisme sehingga tidak merugikan diri dan menyakiti oranglain.

Berpasrah merupakan strategi koping yang digunakan oleh responden dengan cara mengupayakan sesuai dengan kemampuan yang dimiliki dan menyerahkan semuanya kepada Tuhan serta mencoba untuk menerima dan menjalani dengan perasaan ikhlas. Strategi koping tersebut sejalan dengan salah satu aspek koping religius positif yaitu collaborative religious coping (Pargament, 1997), dimana individu mencari kontrol melalui hubungan kerjasama dengan Tuhan dalam pemecahan masalah. Ketika individu menghadapi permasalahan, individu mampu berusaha, berdoa, dan merasakan bimbingan serta petunjuk dari Tuhan. Responden juga melihat kehadiran anak dengan autisme di tengah-tengah keluarga merupakan jalan yang terbaik yang diberikan oleh Tuhan. Sejalan dengan benevolent religious reappraisal (Pargament, 1997) dimana individu menggambarkan kembali stresor melalui sudut pandang agama secara baik dan menguntungkan, dimana individu berfikir bahwa Tuhan memberikan yang terbaik bagi dirinya.

Melakukan pengalihan adalah strategi koping yang dilakukan oleh responden dengan cara mencari pengalihan secara mental seperti mencari kegiatan di luar rumah untuk mengurangi stres yang dirasakan responden akibat krisis-krisis yang dialami sebagai ibu dengan anak autisme. Strategi koping ini dilakukan melalui berbagai kegiatan alternatif yang berfungsi untuk mengalihkan perhatian dan pikiran individu akan suatu masalah (Carver, dkk., dalam Arisandy, 2013).

Pencarian informasi adalah strategi koping yang dilakukan oleh responden dengan cara mencari informasi terkait pengobatan dan pendidikan yang dibutuhkan oleh anaknya yang mengalami gangguan autisme. Saat orangtua menyadari adanya perilaku yang menyimpang pada perkembangan dan pertumbuhan anak, maka tindakan yang dilakukan adalah mencari informasi tentang kondisi anak (Ginanjar, 2008). Aktif mencari informasi dilakukan oleh responden dengan cara mengikuti berbagai seminar-seminar parenting, terlibat aktif dalam proses terapi yang dijalani oleh anak, dan menjalin kerjasama dengan terapis yang menangani anak.

Pencarian bantuan adalah strategi koping yang dilakukan oleh responden ketika tidak mampu mengerjakan semua peran secara mandiri karena menimbulkan kelelahan fisik dan perasaan tertekan pada responden. Pencarian bantuan ini dilakukan dengan menjalin kerja sama dengan keluarga 
terutama dalam pembagian tugas pengasuhan seperti membantu untuk menjaga anak, sehingga memungkinkan responden untuk mengerjakan tugas lain atau memiliki waktu untuk beristirahat. Zager (2005) juga mengungkapkan bahwa orangtua yang memiliki anak dengan autisme mungkin memerlukan layanan dukungan tambahan seperti asisten paruh waktu di rumah yang memungkinkan orangtua dapat beristirahat.

Pemecahan masalah bersama adalah strategi koping yang dikembangkan oleh responden untuk mengatasi permasalahan ketika menghadapi konflik dengan suami, yang dilakukan dengan membangun sistem komunikasi yang positif. Pemecahan masalah bersama dilakukan dengan mendiskusikan masalah yang dihadapi secara bersama-sama dengan mengupayakan solusi untuk mencapai suatu kesepakatan (Friedman, 1998). Dengan mengembangkan mekanisme penyesuaian diri dan mekanisme koping dalam mengatasi permasalahan sehari-hari, responden dapat mengoptimalkan peran dan memberikan pengasuhan sesuai dengan kebutuhan anak.

Selain mengembangkan mekanisme penyesuaian diri dan mekanisme koping, terdapat juga faktor yang menjadi alasan bagi responden untuk terus berusaha menyesuaikan diri dan mengatasi krisis-krisis yang dialaminya. Faktor tersebut dibagi menjadi dua bentuk, yaitu faktor internal dan faktor eksternal.

Faktor internal pertama adalah religiusitas. Kehadiran anak dengan autisme membuat responden semakin mendekatkan diri dengan Tuhan, berpasrah pada kehendak Tuhan, dan meminta petunjuk kepada Tuhan dalam menyelesaikan setiap permasalahan. Religiusitas juga muncul sebagai landasan utama individu menemukan ketenangan diri dan batin, hal ini dapat memunculkan suatu bentuk ketahanan diri (resiliensi) dalam diri individu, ditengah krisis yang dialaminya (Ayu, 2012).

Faktor internal yang kedua adalah kemampuan diri untuk mengekspresikan pikiran dan perasaan, yaitu dengan bercerita mengenai apa yang dialami dan yang dirasakan oleh responden selama mengasuh anak dengan autisme. Menurut Grotberg (2005) kemampuan mengekspresikan pikiran dan perasaan merupakan salah satu dari tiga faktor yang dapat mendorong pencapaian resiliensi, yaitu faktor I Can, dimana individu mampu mengekspresikan berbagai macam pikiran dan perasaan kepada orang lain dan dapat mendengarkan apa yang oranglain katakan dan merasakan perasaan oranglain, mengatur perasaan dan dorong di dalam dirinya, dan dapat mengembangkan hubungan yang dapat dipercaya. Dengan kemampuan mengekspresikan pikiran dan perasaan, ibu merasa lebih tenang karena dapat mengeluarkan emosi-emosi negatif yang dirasakan. Kemampuan mengekspresikan pikiran dan perasaan termasuk salah satu kemampuan sosial yang dapat menjadi faktor pelindung untuk mengurangi risiko dari krisis-krisis yang dialami oleh ibu dengan anak autisme (Robertson, 2012).

Faktor internal yang terakhir adalah harapan. Dengan memiliki harapan, responden dapat lebih termotivasi dalam menjalani kehidupan terutama dalam memberikan pengasuhan yang optimal bagi anak. Harapan memiliki makna sebagai penggerak, yaitu sebagai katalis antara individu dengan tujuan yang ingin diraih, yang dapat menguatkan individu dalam menghadapi kesedihan dan stres selama pengasuhan anak dengan gangguan autisme, sehingga individu dapat melalui berbagai situasi sulit yang dialami (Monsson, 2010).

Faktor eksternal pertama adalan dukungan sosial. Dukungan sosial yang diperoleh oleh responden dalam penelitian ini berupa dukungan emosional, dukungan penilaian, dukungan instrumental, dan dukungan informasi. Dukungan sosial yang diperoleh responden berasal dari keluarga, sesama orangtua dengan anak autisme, lingkungan sekitar, dan juga terapis. Lord \& McGee (2001) membagi dukungan ke dalam dua bentuk yaitu dukungan formal dan dukungan informal. Dukungan formal bersumber dari sekolah, sedangkan dukungan informal diperoleh dari hubungan dengan orangtua lainnya, keanggotaan dalam suatu komunitas yang menyediakan dukungan (support groups), dan keluarga serta tetangga. Sundberg, Winebarger, \& Taplin (2007) mengungkapkan bahwa dukungan sosial merupakan faktor pelindung terhadap stres. Dukungan sosial yang diperoleh dari berbagai sumber dapat membantu responden untuk mengatasi permasalahan yang dihadapi dan menjadi individu yang resilien. Individu yang memeroleh dukungan sosial pada umumnya cenderung mampu beresiliensi dalam menghadapi kesulitan (Robertson, 2012).

Dalam penelitian ini, responden melaporkan bahwa dukungan yang terbesar yang berarti dirasakan oleh responden adalah dukungan yang berasal dari keluarga terutama dari suami. Dukungan yang diperoleh responden berupa dukungan motivasi dan dukungan instrumental berupa pembagian tugas pengasuhan. Lord \& McGee (2001) menemukan bahwa dukungan yang bersifat ekspresif dari pasangan merupakan prediktor penting dari kualitas pengasuhan di rumah.

Faktor eksternal kedua yaitu perkembangan kondisi anak. Kemajuan yang ditunjukkan oleh anak setelah menjalani pendidikan inklusi, membuat responden merasa senang dan bersyukur, serta menjadi termotivasi dan merasa semangat dalam memenuhi kebutuhan dan memberikan pengasuhan pada anak. Semakin baik perkembangan anak, maka orangtua akan semakin menunjukkan penerimaan yang semakin baik terhadap kondisi anak (Astutik, 2014).

Faktor eksternal ketiga adalah pengalaman orang lain. Pengalaman orang lain menjadi salah satu faktor yang memengaruhi tindakan ibu untuk menjadi resilien. Responden tidak merasa sendiri ketika mengetahui ada orangtua lain yang juga memiliki anak dengan autisme dan membuat responden lebih termotivasi dalam memberikan penanganan yang optimal bagi perkembangan anak. Dengan mengetahui bahwa ada orangtua lain yang memiliki anak perilaku serupa dan telah menerima penanganan dapat menjadi sumber harapan dan strategi praktis bagi orangtua (Charman \& Stone, 2006).

Faktor eksternal yang terakhir adalah lama waktu pengasuhan. Lama waktu pengasuhan yang dimaksud di dalam penelitian ini adalah lama nya waktu yang telah dilalui ibu sejak mendengar hasil diagnosis hingga saat ini. Dalam penelitian ini ditemukan bahwa responden telah terbiasa dan sudah mampu menyesuaikan diri dengan keadaan anak dengan autisme, 
dikarenakan sudah mengasuh anak sekitar 5 tahun hingga 11 tahun sejak anak didiagnosa mengalami ganguan autisme. Pemberian pengasuhan secara mandiri yang dilakukan, membuat responden telah terbiasa menghadapi perilaku anak dengan autisme dan mampu mengatasi permasalahan yang muncul saat mengasuh dan mendampingi anak dengan autisme. Hasil penelitian yang dilakukan oleh Tussofa (2015) terhadap tingkat kecemasan ibu yang memiliki anak autis usia 6-7 tahun menunjukkan bahwa terdapat ibu yang tidak merasakan khawatir pada anaknya karena sudah terbiasa melihat sikap dan tingkah laku anak. Lahey (2007) juga mengungkapkan bahwa reaksi masing-masing individu terhadap stres berbeda-beda, salah satunya dipengaruhi oleh pengalaman stres (prior experiment with the stress) bahwa secara umum, orang yang sudah terbiasa dengan situasi yang menimbulkan stres, akan memiliki stres yang rendah dibandingkan orang yang belum pernah dihadapkan dengan situasi yang menimbulkan stres.

Tindakan yang dilakukan oleh ibu dan faktor yang memengaruhi membuat ibu dapat mencapai resiliensi diri yang positif. Resiliensi adalah hasil adaptasi yang sukses terhadap kesulitan yang ditandai dengan adanya kapasitas untuk memeroleh kembali keseimbangan fisiologis, psikologis, dan dalam hubungan sosial, serta kapasitas untuk terus maju dalam menghadapi kesulitan (Reich, Zautra, \& Hall, 2010). Resiliensi tidak mewakili karakter atau atribut suatu individu, melainkan menunjukkan adanya konsep yang saling berhubungan antara adanya paparan stres dan manifestasi dari hasil penyesuaian diri yang positif. Berdasarkan hasil penelitian diketahui, responden telah mencapai resiliensi diri yang positif yang ditandai dengan kemampuan regulasi emosi, pengendalian keinginan, keyakinan akan kemampuan diri, kemampuan berempati, dan pengambilan hikmah. Reivich \& Shatte (2002) menunjukkan bahwa individu yang beresilien memiliki tujuh aspek resiliensi, yaitu regulasi emosi, pengendalian impuls, optimisme, analisis penyebab masalah, empati, efikasi diri, dan peningkatan aspek positif. Individu yang telah beresilien adalah individu yang telah mampu untuk bangkit kembali dari pengalaman emosional negatif dan dapat beradaptasi secara fleksibel terhadap perubahan tuntutan dari pengalaman yang menekan (Tugade \& Fredrickson dalam Embury \& Saklofske, 2013).

Kesimpulan dari penelitian ini adalah kehadiran anak dengan gangguan autisme di tengah-tengah keluarga menimbulkan krisis bagi ibu, yaitu krisis internal dan krisis eksternal. Krisis internal meliputi perasaan terkejut, perasaan tidak percaya dan tidak menerima hasil diagnosis, munculnya kebingungan, perasaan cemas, perasaan sedih, dan perasaan malu yang berdampak pada interaksi sosial ibu dimana ibu cenderung menutup diri. Sedangkan krisis eksternal yang dialami oleh ibu meliputi beban finansial, konflik peran ganda, kondisi anak dengan autisme, penerapan diet, proses terapi, dan respon lingkungan sekitar. Krisis internal dan krisis eksternal yang dialami oleh ibu dengan anak autisme berdampak pada kondisi fisik dan psikis ibu, aktivitas sehari-hari ibu, dan interaksi ibu dengan lingkungan sosial, serta dapat memicu timbulnya konflik antara ibu dengan ayah.

Untuk dapat mencapai resiliensi, ibu dengan anak autisme mengembangkan mekanisme penyesuaian diri dan mekanisme koping. Mekanisme penyesuaian diri yang dikembangkan oleh ibu dengan anak autisme dibagi menjadi dua yaitu mekanisme penyesuaian terhadap karakteristik anak dan mekanisme penyesuaian terhadap respon lingkungan sekitar. Mekanisme koping yang dikembangkan oleh ibu dengan anak autisme dibagi menjadi dua yaitu emotional focused coping dan problem focused coping.

Berdasarkan hasil penelitian dapat dikatakan bahwa ibu dengan anak autisme telah mencapai resiliensi diri yang ditandai dengan kemampuan regulasi emosi, pengendalian keinginan, adanya keyakinan akan kemampuan diri, kemampuan berempati, mampu mengambil makna dan hikmah dari setiap permasalahan yang dialami.

Saran yang dapat diberikan pada orangtua terutama ibu dengan anak autisme adalah agar mengembangkan mekanisme penyesuaian diri terhadap karakteristik anak dengan menjalin kedekatan dengan anak, memperkaya diri dengan pengetahuan dan keterampilan, dan terlibat secara penuh dalam proses pendidikan anak baik ketika anak berada di tempat terapi maupun di rumah. Hal ini bertujuan agar orangtua terutama ibu dapat mengetahui kondisi perkembangan anak dan apa yang dibutuhkan oleh anak dengan autisme, serta dapat meningkatkan penerimaan diri sepenuhnya terhadap kelebihan maupun kekurangan yang dimiliki oleh anak yang dapat menciptakan hubungan interpersonal yang positif antara ibu dan anak dengan autisme. Orangtua terutama ibu dengan anak autisme juga diharapkan dapat mengembangkan strategi koping atau penyelesaian masalah secara adaptif dengan cara bersikap terbuka terhadap segala informasi melalui sharing dengan sesama orangtua yang memiliki anak dengan autisme maupun tenaga pendidik atau terapis yang menangani anak dan menumbuhkan harapan serta keyakinan di dalam diri bahwa anak mampu berubah ke arah yang lebih baik.

Kepada anggota keluarga lain, keterlibatan suami dan saudara (siblings) dalam tugas pengasuhan dapat menjadi sumber dukungan yang berarti bagi ibu dengan anak autisme. Hal tersebut memungkinkan ibu memiliki waktu untuk dirinya sendiri seperti untuk menjalankan hobi atau waktu untuk beristirahat, sehingga dapat mengurangi kelelahan fisik maupun psikologis yang dirasakan oleh ibu sebagai dampak dari kehadiran anak dengan autisme di tengah-tengah keluarga.

Kepada pendidik dan terapis diharapkan agar menjalin kerjasama yang positif dengan orangtua; mempertimbangkan untuk melibatkan orangtua terutama ibu di dalam proses pemberian terapi yang dijalani oleh anak, sehingga dapat menjadi acuan dan referensi bagi ibu dalam menangani perilaku anak dengan autisme; dan juga diharapkan dapat memberikan dukungan kepada orangtua terutama ibu dengan anak autisme.

Kepada pemerintah diharapkan dapat meningkatkan kepercayaan orangtua dengan anak autisme terhadap kualitas layanan terkait dengan kebijakan pembebasan biaya terapi yang telah ditetapkan oleh pemerintah, melalui pemberian pelatihan bagi terapi dan melakukan sertifikasi terutama bagi terapis atau tenaga pendidik yang tidak memiliki latar belakang pendidikan yang sesuai. Selain itu pemerintah juga diharapkan dapat 
memberikan edukasi bagi orangtua dengan autisme, sehinga oransgtua terutama ibu dapat menjadi agen utama dalam mendidik anak dengan autisme. Pemerintah juga diharapkan untuk menaruh perhatian mengenai isu gangguan autisme dengan memberikan edukasi melalui penyuluhan dan sosialisasi kepada masyarakat. Hal ini bertujuan untuk menghilangkan stigma negatif mengenai anak dengan autisme, memberikan informasi bagi masyarakat mengenai layanan publik yang tersedia bagi anak dengan autisme, dan meningkatkan kesadaran serta kesiapan pada pasangan suamiistri terhadap gangguan autisme sehingga memungkinkan anak mendapatkan penanganan sejak dini.

Bagi peneliti selanjutnya diharapkan menggunakan significant others dari segala aspek seperti dari pasangan (suami) atau keluarga responden, agar memeroleh data yang berasal dari berbagai sudut pandang dan data menjadi lebih komprehensif terkait melihat bagaimana kehidupan ibu dengan anak autisme. Selain itu, peneliti selanjutnya diharapkan dapat lebih peka dalam melihat kemungkinan adanya faktor-faktor lain yang dapat memengaruhi tindakan yang dilakukan ibu dalam usaha mencapai resiliensi diri yang positif. Peneliti selanjutnya juga diharapkan untuk memberikan form bagi responden yang terlibat di dalam penelitian saat mengadakan member check untuk dapat meningkatkan otentisitas dan menjadi bukti bahwa telah diadakannya member check.

\section{DAFTAR PUSTAKA}

American Psychiatric Association. (2013). Diagnostic and statistical manual of mental disorders (5th ed.). Washington, DC: Author.

Arisandy, A. (2013). Pengaruh pengalaman tinggal di pesantren, jenis kelamin, dan latar belakang fakultas terhadap strategy coping mahasiswa baru universitas islam negeri (UIN) maulana malik Ibrahim Malang. Skripsi. Program Studi Psikologi, Fakultas Psikologi, Universitas Islam Negeri Maulana Malik Ibrahim Malang.

Astutik, S. (2014). Penerimaan orangtua terhadap anak berkebutuhan khusus. Skripsi. Program Studi Psikologi, Fakultas Dakwah dan Komunikasi, Universitas Islam Negeri Sunan Ampel Surabaya.

Ayu, R. A. (2012). Hubungan religiusitas dengan resiliensi pada ibu yang memiliki anak retardasi mental. Skripsi. Program Studi Psikologi, Fakultas Psikologi, Universitas Kristen Satya Wacana.

Benderix, Y., Nordstrom, B., \& Sivberg, B. (2006). Parents' experience of having a child with autism and learning disabilities living in a group home: A case study. Autism: the international journal of research and practice, 10(6), 629641. doi: 10.1177/1362361307070902.

Burrows, R. (2010). Is anyone listening? A report on stress, trauma and resilience and the supports needed by parents of children and individuals with ASD and professionals in the field of autism in Nothern Ireland. Northern Ireland's Autism Charity. Diakses

dari http://www.autismni.org/attachments/download/274/Is\%20 Anyone\%20Listening\%202010(1).pdf

Charman, T., \& Stone, W. (2006). Social and communication development in autism spectrum disorders: Early identification, diagnosis, and intervention. New York, London: The Guildford Press.
Cohen, D. J., \& Volkmar, F. R. (1997). Handbook of autism and pervasife development disorder (2nd ed.). New York: John Wiley \& Sons. Inc.

Embury, S. P., \& Saklofske, D. H. (2013). Resilience in children, adolescents, and adults. New York: Springer.

Faradz, S. M. H. (2003). Konferensi Nasional Autisme-1. Perhimpunan Dokter Spesialis Kedokteran Jiwa Indonesia, Jakarta.

Fitri, L. (2017). Komunikasi interpersonal berbasis Metode Maternal Reflektif (MMR) antara ibu dan anak berkebutuhan khusus tunarungu: studi kasus keluarga di SLB Ngelom Taman Sidoarjo. Skripsi. Program Studi Ilmu Komunikasi, Fakultas Dakwah dan Komunikasi, Universitas Islam Negeri Sunan Ampel Surabaya.

Friedman, J. (1998). Family nursing: Theory and practice (ed.3). California: Appleton \& Lange.

Gabriels, R., \& Hill, D. (2007). Growing up with autism: Working with school-age children and adolescents. New York: Guilford Publications, Inc.

Ginanjar, A. S. (2008). Menjadi orang tua istimewa: Panduan praktis mendidik anak autis. Jakarta: Penerbit Dian Rakyat.

Gross, J. J. (2014). Handbook of emotion regulation (2nd ed.). New York, London: The Guildford Press.

Grotberg, E. H. (2005). A guide to promoting resilience in children: Strengthening the human spirit. Benard: Van Leer Foundation.

Gupta, A., \& Singhal, N. (2004). Positive perceptions in parents of children with disabilities. Asia Pacific Disability Rehabilitation Journal, 15(1), 22-35.

Hallahan, D. P., Kauffman, J. M., \& Pullen, P. C. (2009). Exceptional learners: An introduction to special education. United States of America: Pearson Education, Inc.

Harta, W. S. (2015). Gambaran source of parenting self-efficacy pada ibu yang memiliki anak autis. Skripsi. Program Studi Psikologi, Fakultas Psikologi, Universitas Padjadjaran.

Hartuti, H., \& Mangunsong, F. M. (2009). Pengaruh faktor-faktor protektif internal dan eksternal pada resiliensi akademis siswa penerima bantuan khusus murid miskin (BKMM) di SMA Negeri di Depok. Jurnal Psikologi Indonesia, 6(2), 107-119.

Hertianna, D. U. (2013). Program pelatihan orangtua untuk intervensi dini anak dengan gangguan komunikasi. Tesis. Program Studi Pendidikan Kebutuhan Khusus Sekolah Pascasarjana, Universitas Pendidikan Indonesia.

Istiqamah, N. (2012). Faktor-faktor yang berhubungan dengan penerimaan keluarga terhadap anak autis di Klinik Taman Pelatihan Harapan Makassar 2012. Skripsi. Program Studi Keperawatan, Fakultas Kedokteran dan Ilmu Kesehatan, Universitas Islam Negeri Alauddin Makassar.

Jarbrink, K., Fombonne, E., \& Knapp, M. (2003). Measuring the parental, service and cost impact of children with autistic spectrum disorder: A pilot study. Journal of Autism and Developmental Disorder, 33(4), 395-402. doi: 10.1023/A:1025058711465.

Lahey, B. B. (2007). Psychology: An introduction (9th ed.). New York: The McGraw-Hill Companies.

Lazarus, R. S., \& Folkman, S. (1984). Stress, appraisal, and coping. New York: Springer Publishing Company.

Lord, C., \& McGee, J. (2001). Educating children with autism. Washington: National Academy Press.

Mansur. (2016). Hambatan komunikasi anak autis. Al-Munzir Jurnal Kajian Ilmu-Ilmu Komunikasi dan Bimbingan Islam, 9(1), $80-96$.

Monsson, Y. (2010). The effects of hope on mental health and chronic sorrow in parents of children with autism spectrum disorder. Doctoral Dissertation. Department of Psychology, Faculty of Graduate School, University of Kansas. 


\section{C.P.D.C DEWI DAN P.N WIDIASAVITRI}

Pamungkas, A. P. (2015). Pelatihan keterampilan pengasuhan autis untuk menurunkan stres pengasuhan pada ibu dengan anak autis. EMPATHY Jurnal Fakultas Psikologi, 3(1), 1-22.

Pargament, K. I. (1997). The psychology of religion and coping: Theory, research, practice. New York: Guilford Publications.

Phelps, K. W., McCammon, S. L., Wuensch, K. L., \& Golden, J. A. (2009). Enrichment, stress, and growth from parenting an individual with an autism spectrum disorder. Journal of Intellectual \& Developmental Disability, 34(2), 133-141. doi: 10.1080/13668250902845236.

Pottie, C. G., Cohen, M. S., \& Ingram, K. M. (2008). Parenting a child with autism: contextual factors associated with enhanced daily parental mood. Journal of Pediatric Psychology, 34(4), 419-429. doi: 10.1093/jpepsy/jsn094.

Puspitha, F. C., \& Berawi, K. N. (2016). Terapi diet bebas gluten dan bebas casein pada autism spectrum disorder. Jurnal Majority, 5(1), 38-42.

Rahayu, E. W., Karini, S. M., \& Karyanta, N. A. (2014). Hubungan antara kematangan emosi dan dukungan emosi dengan penerimaan pada ibu yang memiliki anak autis di SLB Negeri Semarang. Jurnal Ilmiah Psikologi Candrajiwa, 3(3), 171-184.

Ramadayanti, S., \& Margawati, A. (2013). Perilaku pemilihan makanan dan diet bebas gluten bebas kasein pada anak autis. Journal of Nutrition College, 2(1), 35-43.

Reich, J. W., Zautra, A. J., \& Hall, J. S. (2010). Handbook of adult resiliency. New York: The Guilford Press.

Reivich, K., \& Shatte, A. (2002). The resilience factor: 7 essential skill for overcoming life's inevitable obstacle. New York, Broadway Books.

Robertson, D. J. (2012). Resilience: Teach yourself how to survive and thrive in any situation. London: Hachette UK.

Rufaidah, N. (2014). Penerimaan diri orangtua tunggal yang mempunyai anak autis. Skripsi. Program Studi Psikologi, Fakultas Psikologi dan Kesehatan, Universitas Islam Negeri Sunan Ampel Surabaya.

Safaria, T. (2005). Autisme: Pemahaman baru untuk hidup bermakna bagi orangtua. Yogyakarta: Graha Ilmu.

Sarafino, E. P., \& Smith, T. W. (2011). Health psychology: Biopsychosocial interaction (7th ed.). New York: John Wiley \& Sons, Inc.
Sofia, A. D., Ropi, H., \& Mardhiyah, A. (2012). Kepatuhan orang tua dalam menerapkan terapi diet gluten free casein free pada anak penyandang autisme di Yayasan Pelitan Hafizhdan SLBN Cileunyi Bandung. e-Journals, 1(1), 1-15.

Strauss, A., \& Corbin, J. (2017). Dasar-dasar penelitian kualitatif: Tatalangkah dan teknik-teknik teoritisasi data (Cetakan V). Yogyakarta: Pustaka Belajar.

Sundberg, N. D., Winebarger, A., \& Taplin, J. R. (2007). Psikologi klinis: Perkembangan teori, praktik, dan penelitian (Edisi 4). Yogyakarta: Pustaka Belajar.

Suraiya, M., \& Astuti, Y. D. (2008). Faktor-faktor stres pada orangtua anak autis. Naskah Publikasi. Program Studi Psikologi, Fakultas Psikologi dan Ilmu Sosial Budaya, Universitas Islam Indonesia.

Susanto. (2010). Analisis pengaruh konflik kerja-keluarga terhadap kepuasan kerja pengusaha wanita di Kota Semarang. Jurnal Aset, 12(1), 75-85.

Susilowati, A. T. (2007). Hubungan antara dukungan sosial dan tingkat stres orangtua dari anak autis. Skripsi. Program Studi Psikologi, Fakultas Psikologi, Universitas Sanata Dharma.

Suyasa, P. T. Y., \& Wijaya, F. (2006). Resiliensi dan sikap terhadap penyalahgunaan zat (studi pada remaja). Jurnal Psikologi, $4(2), 102-118$

Tussofa, M. (2015). Tingkat kecemasan ibu yang memiliki anak autis usia 6-7 tahun di sekolah luar biasa semesta Mojokerto. KTI D3 Keperawatan.

Veague, H. B. (2010). Autism. New York: Chelsea House Publisher.

Wahyuni, S. (2011). Penyesuaian diri orang tua terhadap perilaku anak autisme di Dusun Samirono, Catur Tunggal, Depok, Sleman, Yogyakarta. Skripsi. Program Studi Pendidikan Sosiologi, Fakultas Ilmu Sosial, Universitas Negeri Yogyakarta.

Widodo, T. (2008). Penyesuaian diri ibu yang memiliki anak autis. Skripsi. Program Studi Bimbingan Konseling dan Psikologi, Fakultas Ilmu Pendidikan, Universitas Negeri Malang.

Wulandari, A. E. (2017). Parenting pada single parent (ibu) yang memiliki anak autis. Jurnal Pendidikan dan Pengajaran Anak Usia Dini, 4(1), 76-81.

Zager, D. (2005). Autism spectrum disorders: Identification, education, and treatment. New Jersey: Lawrence Erlbaum Associates, Publishers. 


\section{LAMPIRAN}

Gambar 1

Paradigma model

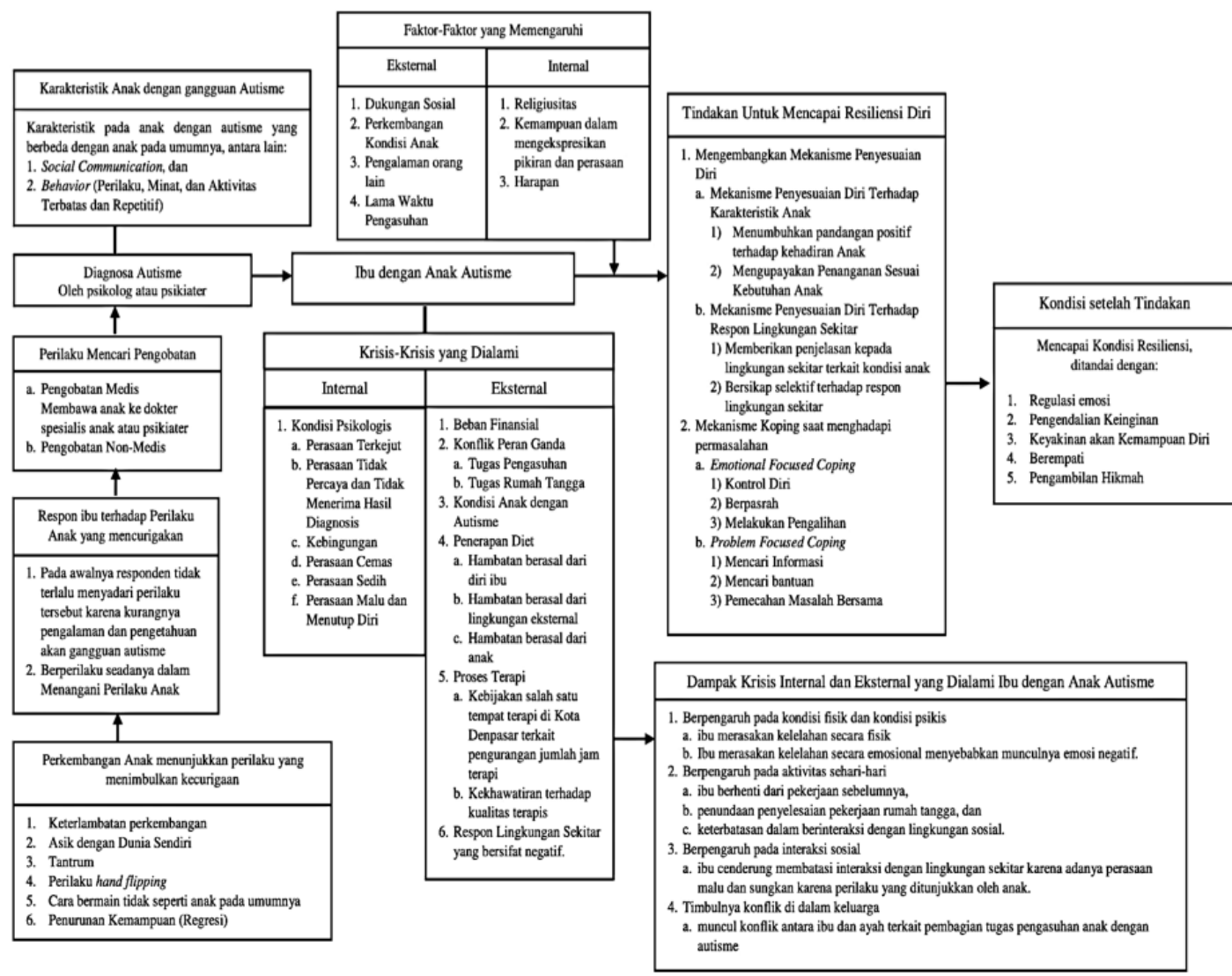

Gambar 2

Reseliensi ibu dengan anak autisme
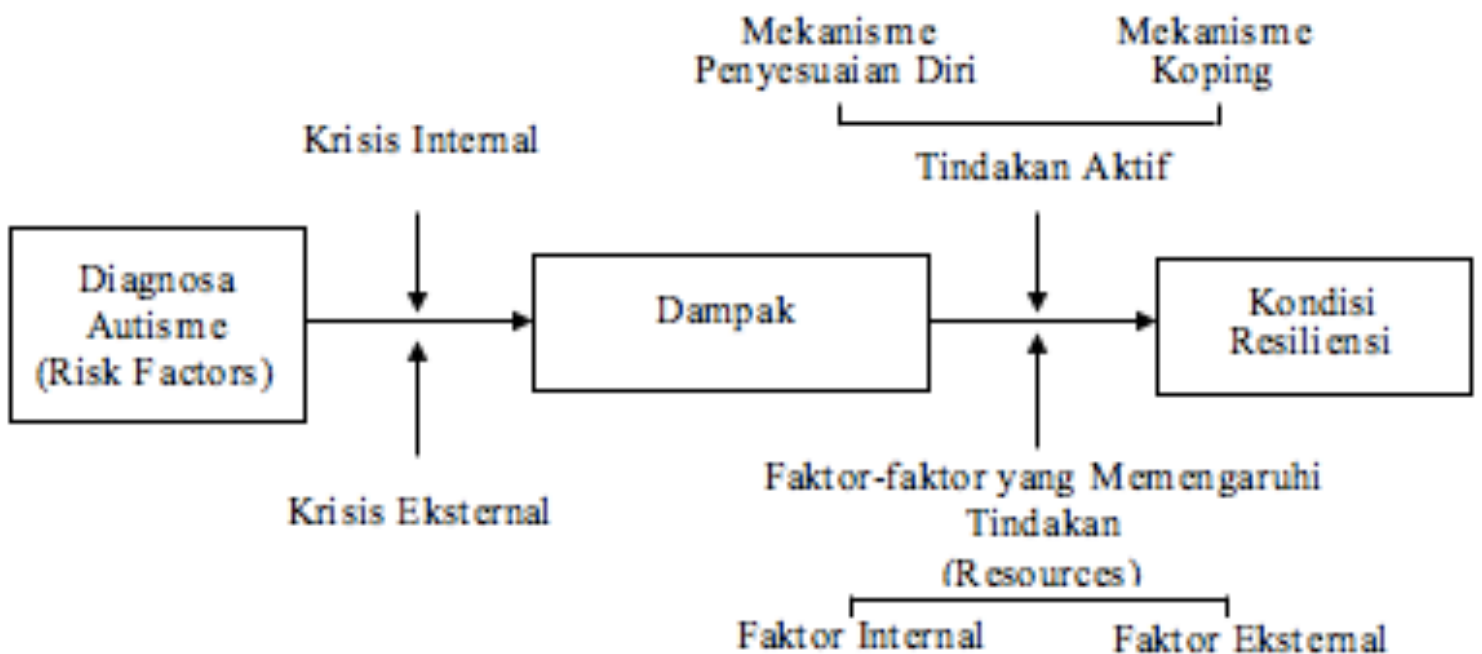